Western University Scholarship@Western

Centre for the Economic Analysis of Property Centre for the Economic Analysis of Property

Rights. Economics and Law Workshop Papers

Rights

1983

\title{
Information, Uncertainty, and the Transfer of Property
}

Douglas Baird

Thomas Jackson

Follow this and additional works at: https://ir.lib.uwo.ca/economicsceapr_el_wp

Part of the Economics Commons

Citation of this paper:

Baird, Douglas, Thomas Jackson. "Information, Uncertainty, and the Transfer of Property." Centre for the Economic Analysis of Property Rights. Economics and Law Workshop Papers, 83-05. London, ON: Department of Economics, University of Western Ontario (1983). 
ECONOMICS AND LAW WORKSHOP

$$
\text { 83-05 }
$$

INFORMATION, UNCERTAINTY, AND

THE TRANSFER OF PROPERTY

by

Douglas Baird*

and

Thomas Jackson**

March 10, 1983 4:00 p.m. Room 4032 SSC

Major funding for the Centre for Economic Analysis of Property Rights has been provided by the Academic Development Fund, The University of Western Ontario. Additional support has come from The Bureau of Policy Coordination, Consumer and Corporate Affairs. The views expressed by individuals associated with the Centre do not reflect official views of the Centre, The Bureau of Policy Coordination, or The University of Western Ontario.

Subscriptions to the Workshop papers and the Working Paper Series are $\$ 40$ per year for institutions and $\$ 25$ per year for individuals. Individual copies, if available, may be purchased for $\$ 3$ each. Address all correspondence to John Palmer, Centre for Economic Analys is of Property Rights, The University of Western Ontario, London, Ontario, CANADA N6A 5C2. 
Draft of: $2 / 21 / 83$

\section{INFORMATION, UNCERTAINTY, AND THE TRANSFER OF PROPERTY Douglas Baird* and Thomas Jackson**}

The origin of private property remains a mystery. How is it that a sea shell, a gold mine, or a whale becomes the property of a particular individual? Does one acquire property through labor?l Does one acquire property simply by taking first possession of it? 2 or is property entirely a creature of positive law?3 After one discovers the source of private property, one still must justify the rules governing its transfer. An individual does not fully "own" a piece of property, at least as we have come to think of ownership, unless he has the power to trade it, 4 but the law typically does not recognize a consensual transfer of property without more. Legal rules require owners to go through prescribed rituals, such as transfering possession of the property or noting one's interest in a public filing system. In this paper, we offer such a justification for these formalities, and we argue that these rules, for the most part, benefit both present and would-be owners.

Few of us who own property actually reduced it to private property from a state of nature (or ownership in common). Our exclusive enjoyment of most property rests on our ability to 
acquire it from someone else. Other things being equal, we would like some means of ensuring that we actually acquire good title when we try to acquire a piece of property. We want, for example, some assurance that our transferor had not already conveyed the property to someone else. The value everyone (including the first owner) puts on property turns, in some measure, on his ability to convince others that he can convey good title. The various rules governing the transfer of ownership rights in property ensures that whoever owns a piece of property can dispose of it or its incidences readily and that whoever acquires an interest in property can be confident that he is acquiring good title or rights to the property.

Two basic types of legal rules limit the free transfer of property: rules that tie ownership of property to the fact of possession and rules that tie ownership of property to information contained in a public recording system. We examine, in this paper, what may make one system preferable to another for different kinds of property and for different types of ownership claims. We then go on to examine the question of the extent to which these rules should be the exclusive source of ownership rights. We examine whether, for example, one's ownership rights should turn not only on the information imparted by possession or a recording system, but also on information acquired from other sources, and whether one's ownership rights should turn on whether one actually relied on the information imparted by posssession or the recording system. Before we approach these questions, however, we want to examine the general contours of 
rules governing transfer and, in particular, rules governing the rights of those who have a thief or dishonest agent in their chain of title. Rules governing transfer in these cases sometimes do not merely supplement a requirement that transfers of property be consenual, but actually replace it.

\section{Transfers of Property, Voidable Title, and the Thief}

If one buys a sea shell in a shop, how can one be sure that the person selling the shell has the power to convey good title? It is all well and good to say, as one theory does, that initially the shell became private property when someone first took possession of it, but how does any individual beachcomber determine that he was, in fact, first to find it? Assuming he is in fact the first, what steps does the first finder have to take to ensure that the shell remains his? Does he have to remain in possession? Can he still assert that he owns the shell if it is stolen from him and he discovers the shell in someone else's hands decades later?

A legal regime might recognize agreement between the present and the would-be owner as both a necessary and a sufficient condition of the transfer of property. In such a world, one would determine ownership rights by tracing everyone's title back to the person who first reduced it to private property (by possession, effort, original entitlement, or whatever). A person's ownership of the shell would turn on whether it had been transferred voluntarily from the original owner to others and 
eventually to him. But even if one acts in perfect good faith and buys the shell from a merchant in the ordinary course of his business, in such a consensually-determined transfer system, one acquires property subject to the risk that there is a thief in his chain of title, unless one can trace the property back to its creation.

In such a system of private property, all ownership claims would be traceable to the act (the labor or the taking of possession) that turned the shell into private property in the First instance. Such a system seems the most consistent with the underlying theory governing the creation of private property. A rule that, for example, allowed good faith purchaser to take despite a thief in the chain of title, would sanction the existence of private property, even where neither the present possessor nor anyone else in his chain of title has done what was necessary to create property in the first instance.

Nevertheless, a rule that recognized title under these circumstances might promote everyone's interest in the long run by giving those who bought in good faith confidence that they owned anything they acquired in good faith. People might agree, if asked before they acquired property, to a system of transfers that to some extent did not depend on actual consent at the time of the transfer. 5 such a system is still consensual in its justifications, but consent is both hypothetical and general, rather than actual and transaction-specific.

One may have to reconcile everyone's interest in enjoying property that is acquired from someone else and the importance of 
recognizing the rights of the person who first owned it or who last owned it by wholly consensual transfer. Such an accommodation is by no means an easy one. One may, for example, decide that a system of transfers must weigh the derelictions of the original owner, who perhaps enabled the theft, against the entitlements of a morally innocent purchaser. The original entitlement question is, almost of necessity, but a part of a larger picture.

Different systems governing the transfer of private property have existed at different times. The law merchant placed a premium on the free transferability of goods, 6 and it gave bona fide purchasers of goods exclusive right to those goods, even if there were a thief in the chain of title, as long as the goods were purchased in a market overt from their possessor. 7 By contrast, the general common law rule protected true owners of property if goods were stolen from him by a thief. 8 But, by the middle of the 19th Century, if an owner lost the property through the defalcations of a dishonest agent, he was at risk as against the good faith purchaser for value whose rights to the property were derived from the dishonest agent. 9 The person who created private property in the first instance had his right of exclusive enjoyment limited by the rule that he could lose his property through the dishonest acts of those whom he knew and with whom he dealt. Similarly, the good faith purchaser for value could enjoy exclusive rights in a piece of property, even though he could not trace his rights back to the original owner through a string of 
consensual agreements, as long as he did not have a thief in his chain of title.

These common law rules governing transfer -- in particular the rule that says that a dishonest agent can extinguish one's ownership rights -- may place risks on those best able to bear them. The person who employs a factor to sell goods on his behalf may be in a better position to judge the factor's day-today honesty, and to pay for it as a cost of business, than someone who purchases goods from him in a one-shot sale or from time to time. Similarly, the Uniform Commercial Code's rule that protects buyers in ordinary course of business may embody the same idea.10 A buyer in ordinary course of business who buys from a merchant who was entrusted with possession of goods prevails against the original owner, even if the merchant had no right to sell the goods. The person who entrusts the goods to the merchant may again be in a better position to judge the honesty of the merchant than the person who buys from him through what appears to be an ordinary transaction.

The entrusting doctrine, like most legal rules, cuts quite broadly. It applies equally to the manufacturer who regularly takes his goods in to be refurbished to a particular merchant and to the consumer who takes his watch into the jeweler to be repaired. And it applies equally to the wholesaler who regularly buys merchandise from a manufacturer and to a consumer who buys a camera from the local camera store. Given the diversity of applications, a rule that gave paramount rights to the good faith purchaser for value in both situations might not always be 
putting the burden of checking for the dishonesty of the merchant on the person who is best able to ferret it out.

But it is one thing to say that the rule does not work perfectly, and quite another thing to say that the rule is not, all things considered, better than the alternatives. The costs of a more open-textured standard (for example, case-by-case application of a principle that placed the risk on the party best able to bear it) might create litigation and uncertainty costs (rot easily shifted by private agreement) that outweighed any advantages that might be derived from having a standard that fitted the principle precisely. In those cases, a rule that, although derived from the principle and fitting but inexactly, may nonetheless be preferable.

The existence of the thief exception to the voidable title principle may remain curious in light of the explanation just suggested. But the ultimate liability in those cases comes to. rest on the person who first acquires the property from the thief.11 It may be that the exception is warranted because, in addition to the deterrent function of the rule in depriving the thief from some of the fruits of his theft (by lowering its value), 12 the taker from the thief may often be in a better position to prevent the harm than is the original owner whose mistake, if any, was in not guarding the property more closely.13 


\section{Different Kinds of Property and the Different Systems of Title}

The transfer of private property affects the entire world. Imagine that smith is (or at least once was) the true owner of Blackacre. To say that Jones bought Blackacre from Smith is to say more than simply that as between the two, Jones' rights to Blackacre are superior. When Jones buys Blackacre from Smith, Jones wants to be sure that no one else will enjoy rights superior to his. He wants to ensure, for example, that he will prevail against anyone to whom Smith purported to sell Blackacre last week and against anyone to whom he purports to sell

Blackacre next week. But how can Jones distinguish himself from these others, who are equally interested in obtaining good title to Blackacre?

Rules governing the transfer of property are desirable because, properly drawn, they can make it easier to find out who the true owner of the property is. The variety of filing and possessory systems that exist work to minimize the costs of gathering information about ownersinip. In order to give everyone assurance that their title is paramount, we can (and, in fact, do) require that anyone who claims rights to the property to assert his rights in a way that gives notice to everyone else. The more certain that Jones is regarding his rights to Blackacre, the more readily Jones either will invest the time, energy, and resources in putting Blackacre to Jones' best use for it or will be able to transfer it to someone else who values it more.14 But 
Jones will not insist on perfect information when Jones acquires Blackacre, for perfect information may be so costly to produce that Jones is better off with a lesser quantum of information and some uncertainty, because it is cheaper for him to bear the uncertainty (or to insure against it) than it is to eliminate it. Rules governing the transfer of property reflect sensible tradeoffs between information and uncertainty.

At one time, taking physical possession of real or tangible personal property was necessary before Jones could be relatively certain that his claim was, and would remain, superior to that of others was by taking physical possession of the property. This system depended on a vary simple legal rule (and hence on minimal government intervention): To obtain priority in an asset over third-party claimants, one needed, in addition to the consent of the prior owner, to take physical possesion of the asset. Under such a system, both the obtaining of information regarding prior claims and the disseminating of information regarding one's own claim, was simple -- one took possession. As between the parties to a transaction, such as lender and the true owner, their private contract governed. But as against most of the rest of the world, possession was also necessary.

Establishing ownership rights from possession, however, brings costs. A possession-based rule of title determination would, for example, have impeded temporal divisions of real property, such as life estates.15 Because land is permanent and is easy to identify, it is an ideal candidate for a set of rules governing transfer based on a recording system, where the legal 
rule defines the scope of the relevant information. Under such a regime, one acquires ownership of Blackacre by engaging in certain public acts. This permits others who come later to discover the true owner very easily. As a first approximation, one has exclusive ownership of Blackacre to the extent that no one else, outside his chain of title, has engaged in these acts before, and one can learn about all these earlier acts, because they (notations in a filing system) are both permanent and publicly accessible.16

Because land is permanent and chains of title are long, those who acquire title must be able to trace their title back very far. Written records that last through many life-times are therefore preferable to any public spectacle involving clods of dirt and the like. Moreover, land is relatively valuable. The cost of maintaining a title system -- both the costs of employing a clerk to run it and the costs of obliging everyone who wants to acquire rights in real property good as against the world to make filings -- are therefore small compared to the relative value of the property involved. Land is relatively easy to identify. Though it may be expensive to hire a surveyor to make a metes and bounds description of Blackacre and to create a title system that reflects it, such a survey needs to be done only once, and, done properly, provides an unambiguous description of the property.

A filing systein needs to have some organizing principle, for potential purchasers need to know which of many files in many jurisdictions is the relevant one. Because one can require filings to be made in the jurisdiction in which the land is 
located, determining which file to check is rarely difficult in the case of real estate. In short, in the case of real property total strangers can identify it -- and know where to look for record ownership of it -- from one day to the next (indeed from one century to the next) with reasonable confidence.17

The provisions recording transfer of title of real property successfully deals with the need of potential purchasers of property to acquire reliable information about who owns the land he wishes to acquire that does not suffer from the infirmities of a possession-based system. The title system has the effect of reducing the uncertainty surrounding a transfer of real property. The effect is to increase the value of property generally, for the more effective the set of rules governing the transfer of property, the more valuable it is to own property in the first instance.

A title recording system also largely eliminates the problem of thieves in the chain of title. To establish ownership of property, one obtains relevant information concerning possible competing claims based on what the title system says. Moreover, the title system itself generally can be relied on. There are, of course, reliability costs to running a filing system, for there can be forged or fraudulently-obtained deeds represent a form of theft. But it is one thing to say that these costs exist, and quite another to say that another system can achieve a better compromise between the information provided and the aggregate costs of providing that information. 
But not all types of property are equally suitable to an informational system based on files. We do not, for example, generally find recording systems for establishing ownership of personal property. The informational advantages that such a system provides do not, as a general matter, seem worth their costs. A title recording system is much harder to organize for grain in a silo. One has no easy way of knowing that this was the grain grown on Blackacre in one jurisdiction or on Whiteacre in another. One also has no easy way of knowing in fact that the grain in the silo today was the grain that was there yesterday.18 One, moreover, cannot easily be sure in what jurisdiction it (or its owner) will be from day to day. Property that is transferrea frequently, moreover, may be unsuited to a recording system because of the costs of using the system. Even though a $\$ 20$ bill can be precisely identified (by serial number), its negotiability would be substantially impeded by a recording system.

Although in an earlier era, personal property distinguished itself from real property in that partial ownership interests in personal property were relatively uncommon, this is no longer the case. Personal property is a common source of collateral. Given the usefulness of secured credit -- that is, given that secured credit enables debtors to borrow more or at lower interest rates because their creditors can monitor them more effectively'19 -the possession principle is an obstacle, for, by and large, it dictates that only one person own a particular piece of property at one time. Using property as financial collateral necessarily demands joint ownership. Most of the sticks in the bundle of 
rights connected with a piece of property belong to the debtor, but some of these rights are owned by the secured party (including, most notably, his right to take possession of the property in the event that the debtor defaults for purposes of repayment).

The common law solution was to allow the creation of security interests by having a debtor transfer possession of personal property to the creditor. 20 This solution, however, was unsatisfactory in two respects. First, it was not truly consistent with the possession principle. To be sure, potential purchasers would not have to worry that their seller had given someone else a security interest in the property, but they would have to worry that their seller did not own the property outright, but simply possessed it as a collateral for a loan he had made. 21 This problem may have been largely a theoretical one, however, for those who were secured lenders (such as pawnbrokers) may have been sufficiently well-defined that those who purchased from them knew that their sellers were lenders and that they were taking their property subject to the risk that their sellers shared ownership with someone else.22

Nevertheless, there is a second problem with having only possessory security interests that is of much more practical concern. People who want to put up personal property as collateral typically want to continue to use it. If they do not need to use the property, they probably would not own it. Although undeveloped real estate is sometimes held as an investment, drill presses are not. 23 But it is difficult for a 
debtor to transfer possession of the property to a creditor and still enjoy the use of it. Common law devices such as the field warehouse achieved this result only awkwardly and only through legal fictions. 24

Over the course of the 19 th century and the first half of this one, the possession principle was supplemented with a filing system that recorded the interests of those who were not in possession. Although based on real estate recording systems, personal property filing systems are in fact fundamentally different. A real estate recording system uniquely identifies a particular piece of property and that recording system itself establishes ownership rights, including title itself, against the world at large. By contrast, Article 9's filing system does not describe individual pieces of property, applies only when possession has not been transferred, does not establish ownership rights in any property, and does not even say that the person staking a claim in the property ever extended credit to the debtor. 25

Article 9's filing system, although it serves a purpose similar to a real estate filing system, is much more limited in scope. It serves largely to organize priorities among one class of property claimants -- secured creditors who do not take possession. As for other kinds of ownership interests, one must rely on possession and, in the case of bailments and leases, on private agreements between parties. We have argued elsewhere that ownership of personal property should be determined exclusively by possession, unless one stakes a claim in a filing 
system, and that private agreements should not affect the rights of third parties. 26 we note here, however, that the decision of the legal system to retain the primacy of possession and to use information from the files only to supplement it, follows from the differences between real and personal property that we have already discussed. Requiring filing to transfer all personal property or even requiring the filing system to contain all the information necessary to determine the ownership rights of secured creditors would probably not be worth the costs it would impose. Even if leases and bailments were folded into the Article 9 filing system, the owner who was in possession of property would remain, unlike the real estate owner, outside the filing system. Article 9's system, even if expanded, is fundamentally not a title system, and hence the role accorded possession is substantially larger.

Filing systems and possession systems are not mutually exclusive. Indeed, as Article 9's filing system has shown, they may be highly complementary. The exact mix of filing and possession-based rules turns on the kind of property involved, as does the form the systems themselves take. Just as filing systems can require more or less information, possession-based systems can require either possession of the property itself, or it can require possession of a piece of paper -- such as a negotiable document of title or a promissory note or a deed -that embodies rights to a particular piece of property. For some personal property -- such as airplanes, cars, and ships -- we do have title recording systems. Although serial 
numbers and the like can be changed, 27 individual airplanes, cars, and ships, like real property, are relatively easy to identify in a unique way. Distinguishing one 747 from another is much easier than distinguishing one ton of wheat from another. Like real property, these items of property tend to be fairly valuable. The cost of creating a public information system is further reduced by licensing and registration laws that require jurisdiction-wide information gathering for these kinds of property in any event.

If one looks at the title recording systems for tangible personal property, however, one notes that the property involved is not at all like real property in one respect. Real property, by definition, never moves. The types of personal property that are subject to recording systems, however, move constantly. A jet airplane will spend much of its life in the air. That real property never moves, however, is relevant only in the sense that the task of deciding which filing system to look at is simple. Mobility of collateral affects only the question of where one establishes a filing system that will contain the relevant information. Legal rules can provide a "which system" answer for mobile property as well. In some cases, such as with airplanes, a federal filing system provides a single, and stable, solution. Automobiles, by contrast, which are not subject to a federal system, create problems when cars are moved from one jurisdiction to another, although these problems are substantially reduced by the presence of a uniform conflicts rule in section 9-103 of the Uniform Commercial Code. 28 
Other kinds of personal property -- such as patents, copyrights and trademarks -- are intangible and cannot be possessed. 'A patent is the exclusive right to make, sell or use a particular new and useful process, machine, manufacture, or composition of matter. This right is abstract. In the absence of a special rule, Jones has no way of knowing whether the inventor smith has transferred his right to someone else. To facilitate the transfer of such intangible property rights, we face a choice between two sorts of legal rules. The first assimilates abstract rights to a possession-based regime. We can have a rule that merges the abstract right into a piece of tangible property, such as a piece of paper. One could acquire the exclusive rights inherent in a patent, by acquiring the piece of paper that embodies the patent right. Jones would know that his rights to the patent were paramount, because smith was still in possession of the piece of paper into which the abstract rights had been merged.

The second alternative is to forego trying to change an abstract right into tangible property and rely on a title system. Under such a regime, rights to a patent (or copyright or trademark) would turn on whether one's interest was properly noted in a public file. To prevail against others to whom Smith might have tried to convey his patent in the past or might try again in the future, Jones must ensure that his interest is properly noted. By and large, transfers of intellectual property are governed by filing rules. 29 Reifying a patent, copyright or trademark might seem to have advantages if all that were at stake 
were outright transfers of these property rights, because the administrative costs of such a system would be very low. The creation of the piece of paper embodying the intellectual property right would be the only official act required, instead of filing system that would have to be constantly maintained and updated. Partial interests (such as security interests) in intellectual properties, however, may tilt the balance decisively in favor of filing-based rules. 


\section{The Role of Know ledge and Reliance in a System of Property Transfers}

Filing systems work because the legal rules provide not only a benefit to a person who desires to acquire a property right (in legally constraining the types or location of information that is relevant to his risk) but also a corresponding responsibility. A lender who wants to acquire a security interest in his debtor's sea shell can discover the relative risk of competing secured claims to that shell by checking the files. But finding out about the absence of prior claims does little good if one cannot also be confident that his interest in the shell takes priority over subsequent claims. To close the circle on the risks surrounding the transfer of the interest in the shell, therefore, one also must cure the ostensible ownership problem that his interest creates by noting his claim of an interest in the files. This benefit and this burden, of course, are but opposite sides of the same coin.

We wish to explore in the remainder of this paper whether the filing system should be viewed as the exclusive way of gaining the information about the existence of prior claims to the asset. Two questions present themselves. The first is the role of actual knowledge in ordering priorities of claims to assets. If the files do not properly reflect the existing clain of an interest of a creditor in a debtor's sea shell, because, for example, that creditor failed to file, or filed improperly, 
or his filing has become improper because of some change in the world, the files cannot be said to impart notice of his interest. One, however, may have actual knowledge of the interest of that creditor, obtained from some other source. If one then acquires a property interest in the shell, should one be able to claim that his actual knowledge does not defeat his priority over the other creditor, because of the absence of notice from the filing system? This inquiry we shall call the question of knowledge, and it asks whether the legal system should treat knowleage as equivalent, for purposes of ordering claims of interests in an asset, as the constructive notice that comes from an interest properly noted in the files.

The second question is whether subsequent parties can point to defects in an earlier party's filing (or the absence of a filing altogether), even if they never checked the filing system and never relied on the absence of proper notice. This inquiry we shall call the question of reliance, and it asks, as between a creditor who fails to file property and a subsequent creditor who fails to examine the files, if there remains any reason for continuing to prefer the subsequent creditor.

Neither of these questions looms large in litigation surrounding real property, in large part because the transactions are sufficiently large and the rituals sufficiently well known that defective filings are the rare exception rather than the rule. Defective filings, however, are an everyday affair when at issue are security interests in personal property, and thus the question is far from being merely of theoretical interest. 


\section{A. Actual Knowledge and Priority Entitlements}

The principle differences among the various filing systems in use today turn on the role of actual knowledge. The three principal recording systems, both in real property law and in pre-Code chattel security law, are "notice," "race-notice," and "race" statutes. 30 Under a "notice" statute, a subsequent purchaser with neither notice nor knowledge at the time of the purchase transaction prevails over a prior purchaser. By absence of notice, we mean that the the filing system does not offer the subsequent purchaser the relevant knowledge. The prior purchaser has failed to record his interest, or at least has failed to do so properly. Under a notice statute, however, knowledge of the prior purchaser's interest at the time of the subsequent purchase transaction, derived from sources other than the filing system, will defeat the claim of the subsequent purchaser to priority despite the defects in the filing system. But, absent knowledge of the prior purchaser's interest at the time the subsequent purchaser enters his transaction, the subsequent purchaser will i)revail whether or not either of the two parties ever files. Under a "race-notice" statute, a subsequent purchaser, if he has neither knowledge nor constructive notice of the claim of a prior purchaser at the time he enters into a purchaser transaction, will prevail if, but only if, he records his claim first. Thus, up to the time of the subsequent purchase transaction, "notice" and "race-notice" statutes are identical in 
their treatment of knowledge: The subsequent purchaser may prevail only if he has neither knowledge nor constructive notice at the time of the transaction. The two statutory schemes diverge only in the post-transaction period: While the "notice" statute treats events occurring after that transaction as irrelevant for purposes of determining the priority as between these two purchasers, the "race-notice" statute imposes an additional "race" requirement in that post-transaction period before priority is ultimately determined.

Under a "race" statute, knowledge gained outside the filing system is irrelevant. The first party to file -- and hence the first party to give constructive notice -- wins. The race system, while it is the purest system in regarding as exclusive the information in the files, exists in very few states with respect to real property. And while Article 9 of the Uniform Commercial Code has, with a few exceptions, adopted a "race" . system for security interests in personal property, this itself is a deviation from most pre-Code chattel mortgage systems. Indeed, prior to the 1956 revisions of Article 9, courts usually read a knowledge requirement into statutes that were otherwise silent. For example, Section 230 of the New York Lien Law provided that a mortgage, unless filed within ten days of its "making," was "absolutely void as against the creditors of the mortgagee and as against subsequent purchasers and mortgagees in good faith . . . " A long line of New York cases, however, held that a subsequent mortgagee (or other purchaser) with knowledge 
of an existing but unfiled mortgage was not in "good faith" and hence took subject to the unfiled mortgage. 31

In so construing the statute, New York was aligning itself with a longstanding common law principle of protecting the good faith purchaser without knowledge. This tendency towards the common law position was especially common in the real property sphere, with the result that "[n]o matter how a statute was worded it came to be construed as protecting the common law priority of the first grantee against all later purchasers with notice... . " 32

The benefits of incorporating knowledge into a system of priorities when there is a filing system to provide constructive notice are, however, not clear-cut. After the fact, it might seem best to incorporate knowledge into the system. Otherwise, legal rules seem to reward those who take advantage of a prior party's failure to comply with the formalities of transfer, and allowing these parties to prevail seems to exalt the largely procedural rules on transfer over the substantive rights themselves.

If we view this in terms of an analogous tort or contract doctrine of mistake, having knowledge supplement the basic set of priorities established by the filing system may seem sensible. After all, the person who possesses knowledge at the time of loaning money, is in a position to protect himself. When one party fails to file notice of his interest, he has, at one level, made a "mistake," the harm of which will fall on him in the form of lost priority. Yet, when a subsequent party has knowledge of 
that mistake, the subsequent party may be thought of as in the best position to prevent the harm from being visited on the other party, by refraining from making the loan. 33

But with respect to most categories of personal property and perhaps of real property as well, it is difficult to see how legal rules make people better off in the aggregate if knowledge supplements the information in the filing system, for there seems to be no effective way to "capture" the benefits of knowledge for that system of transfers of incidents of ownership. We need to recall the role information plays in rules governing the transfer of property. The presence of information in a filing system reduces the uncertainties surrounding the transfer of rights to property. Knowledge gleaned from other sources fulfills this function equally as well insofar as the party with knowledge is concerned. But this does not tell us that those who have knowledge should lose against the party whose error made the filing system inaccurate in the first instance.

The effect of this rule, however fair it might seem after the fact, seems counterproductive when viewed before the fact. A potential purchaser with knowledge of the unfiled interest of another would appear to be deterred, by this rule, both from making a loan (or other purchase) on the asset in question and from gathering information about prior claimants in the first instance. Introducing knowledge into the ordering of priorities, moreover, creates insoluable circular priority problems when more than two parties are involved and one has knowledge of a prior interest and another does not. 34 
We need to establish how parties are made generally better off if, despite the increased uncertainty costs, we abandon a system that makes a filing system the exclusive source of the information it contains and does not contain. A sensible system designed around incorporating knowledge into the ordering of priorities, therefore, must find a way to provide some benefits based on that knowledge. Third parties are not, in the aggregate, better off, unless the knowledge requirement improves the accuracy of the filing system. Does the subsequent party possessing knowledge of a unfiled interest have an incentive to use his knowledge either to correct the files himself or to tell the errant filer of his mistake and allow that party to correct the files? Can knowledge ultimately be incorporated to improve the notice imparted by the files, and reduce the costs of mistakes (either on prior or on subsequent parties) without discouraging people from gathering the knowledge in the first instance?

The method presently used is the "stick" approach of denying priority to a subsequent creditor if he has knowledge of the unfiled interest of another. But because of his knowledge, this purchaser will not pay as much for the asset as would someone else without the knowledge, for this purchaser's enjoyment of the asset can, unlike someone without knowledge, can be trumped by the holder of this unfiled interest.

This purchaser could, of course, compete with the other purchasers by providing them with the knowledge as well, either by telling them directly, or by incorporating it in the files, 
where it would become a part of the file's notice system. But gaining this parity by incorporating the knowledge into the filing system imposes on this purchaser some costs (such as of notification) that the other creditors do not bear. And, after taking such steps, this purchaser then must compete with the owner's other potential purchasers only on an equal (now second priority) basis.

Moreover, implementing a "notice" recording system provides, at best, a "stick" only to a party who actually makes a loar (or other purchase). The presence of that stick is more likely to drive away any party with knowledge than it is to result in having that knowledge incorporated into the transfer system and, at the margin, to discourage people from gathering information in the first instance. Nothing under the present "notice" systems encourages anyone except a subsequent purchaser from imparting the knowledge they have to the filing system. Where there is a well-organized market for the particular type of property in question, this result may tend to drive away the person with information, leaving the "harm" to be imposed on the prior party by another, more ignorant, purchaser.

A market for "unique" goods may exhibit characteristics that make the incorporation of knowledge more feasible. If prices do not cluster around a prevailing norm, the person who has knowledge may not be driven away, but, instead, will still be the purchaser, only one who pays less for the property as a result of his knowledge. In these cases, a knowledge requirement may achieve the result of a "last clear chance" sort of rule: the 
harm to the prior purchaser can be avoided. If the contract doctrine of specific performance accurately reflects the attributes of unique goods that exhibit these qualities, 35 the greater tendency to observe knowledge requirements in land cases may be explicable. Whether land, today, exhibits such qualities, or whether the benefits of incorporating knowledge outweigh its administrative costs, however, may still be an open question.

Even in the case of "ordinary" goods, to say that the current system does not provide an effective mechanism to incorporate knowledge into a system of priorities in transfers based on a filing system, is not to say that a system could not be designed, but any such system is necessarily fraught with problems. For example, consider the possible merits of a "bounty" system. In such a system, some party -- perhaps the creditor who is benefitted or the state -- would pay the person who corrects the files by disclosing his knowledge of the existence of the prior unfiled interest. The amount of the payment might be the costs of the person who makes the correction, or some multiple of those costs, or some fixed amount. While the details would vary, a system such as this would perhaps surmount the difficulties of incorporating the knowledge that the current "stick" approach has.

Yet this approach is not without added costs and disadvantages of its own. If, for example, the correction cost plus the bounty cost were greater than the benefits to the transfer system from incorporating such knowledge, such a rule would ultimately increase the aggregate cost of transfers. A 
bounty, moreover, may lead third parties to invest too many resources in "discovering" such errors in the filing system. 36 The resources invested in discovering such errors turns on the amount of the bounty. If the bounty is large enough to encourage people to add information to the filing system, the costs of providing the bounty may well exceed the benefits of having a more accurate filing system. 37

In sum, there seems to be no clear-cut, low-cost way of conscripting knowledge to correct the filing system in a way that results in a certain net benefit to the system of property transfers. Arrayed against these uncertain advantages, however, would be several (and quite certain) costs. In addition to the ones we have already noted, unless the failure to correct the files and claim the bounty were treated as conclusively establishing that one did not have the requisite knowledge - a possible result, but one largely at odds with the general legal role of knowledge -- one would still face the evidentiary costs of establishing a mental state such as knowledge, or even the existence of such a state of facts that would constitute reasonable "inquiry" knowledge. Another would be the uncertainty costs associated with the possibility of an erroneous determination of the inquiry. Moreover, because it is likely that an important factor in any determination of knowledge would be what the debtor told the secured party, the debtor, in a priority contest, would have an incentive to "sell" his story to the party willing to give him the most for it. 
Although the incorporation of knowledge would indeed be a benefit to the system, it is difficult to envision a system that (even without considering the costs we have just described) is likely to capture a substantial portion of that benefit. The additional proof costs that clearly would result, therefore, seem to us to make out a quite plausible case against the incorporation of knowledge into the recording system.

\section{B. Reliance and Priorities}

Virtually all filing system for real or personal property of which we are aware -- and, indeed, virtually all possessory systems as well -- treat as irrelevant the question of whether or not a purchaser ever inquired into the status of existing claims -- by, for example, checking the files. As a result, transfer systems provide priority to the claim of a subsequent property claimant over that of a prior claimant whose claimed interest is unfiled or improperly filed. This priority, moreover, is not dependent on whether the subsequent property claimant ever bothered to check the files in the first place.

In common parlance, the subsequent party is entitled to priority whether or not he ever "relied" on the files before acquiring his property claim to the asset in question. In a case such as this, the prior party has failed to file (or to file properly), while the subsequent party has failed to check the files (or to check the files properly). Given these dual 
omissions, is there a reason to place the risk on one party rather than the other?

The reason for failing to file or to check may be intentional, in the sense that the party did not find the activity to be worth its costs, or it may be "unintentional," in the sense that it was a "mistake" that, had the party known better, would have avoided. In any event, deciding where to place the risk seems to revolve around a determination of the question of whether there is any particular reason for believing that either of the parties is better able to bear the risk, either because one party is better able to prevent the risk from occurring or because one party is better able to insure against the risk. But, where the comparison is between the failure to file and the failure to check the files, it is difficult to believe that there is a systematic risk-bearing answer to be found here, in any of its relevant garbs.

Incorporating the concept of reliance into a filing system for evidencing the transfer of ownership claims to assets brings, however, two costs that seem to tip the balance against imposing a reliance requirement. The first, and less substantial reason, involves the record-keeping costs associated with incorporating reliance into a filing system. A filing system requires a mechanism for determining the presence and accuracy of a filing. As a corollary of this, a filing system requires a mechanism for recording who claims what ownership rights to a particular asset. Thus, embodied in the concept of a filing system itself is the notion of a mechanism for keeping track of who files. Yet, the 
concept of a filing system does not embody -- and the existing systems do not otherwise incorporate -- a mechanism for

determining whether or not the files were inspected, and by whom. While it would undoubtedly be but a simple process to require the recording of such information, this would nonetheless involve a cost that does not otherwise exist.

A more substantial reason for failing to incorporate reliance into the filing system is the presence of other proof costs such incorporation would entail. To say that a purchaser has not checked the files is not to say that he has not relied, perhaps indirectly, on the presence or absence of information in those files. A purchaser may have knowledge from other sources as to what is in the files, thus obviating the need to check the files himself. More abstractly, a purchaser may "rely" on the information in the files without checking simply by observing the competitive rates for the acquisition of the interest in the property from the debtor. In this way, the purchaser free-rides off information garnered by others,. much as participants in a stock market are gaining the benefits of research by others. Whatever the indirect method of obtaining information about competing claims, these forms of reliance do not lend themselves easily to proof. Incorporating a reliance requirement into the filing system would be a cost to purchasers, in that they could no longer use these other forms of information, but would have to check the files themselves. 


\section{Conclusion}

Establishing and justifying entitlements only begins the task of exploring the foundations of property law. Much of what we mean when we refer to property law is the set of rules that governs the transfer of property after one determines who is entitled to it initially. In this paper, we have argued that these rules -- ranging from livery of seisin38 to symbolic delivery of a ship at sea39 to creation of a security interest in a partially completed motion picture 40 - can be examined critically against a common backdrop. To a large extent, the wisdom of these rules turns in large measure on how successfully they enable present and would-be property claimants to reduce the uncertainties that every assertion of ownership brings. 
FOOTNOTES

* Assistant Professor of Law, University of Chicago

** Professor of Law, Stanford University. Many of the ideas in this paper grew out of valuable exchanges we have had over the past several years with James Krier. We also thank Frank Easterbrook, Richard Helmholz, and Douglas Leslie for their helpful comments.

1 See J. Locke, Two Treatises on Civil Government, Book II, $\S$ 27 (3rd ed. 1966); see Hamilton, Property = According to Locke, 41 Yale L.J. 864 (1932).

2 See Epstein, Possession as the Root of Title, $13 \mathrm{Ga}$. L. Rev. 1221 (1979); L. Becker, Property Rights: Philosophic Foundations $25(1977)$

3 See J. Bentham, Theory of Legislation 113 (4th ed. 1887) ("Property and law are born together, and die together. Before laws were made there was no property; take away laws, and property ceases."). If one assumes that property is entirely a creature of positive law, one may try to justify a set of property rules on the grounds that they promote utility. See, e.g., D. Hume, A Treatise of Human Nature, bk. III, pt. II, $\$ \S 2-4$ at 43659 (Dolphin paperback ed. 1961). 
4 But cf. Andrus v. Allard, 444 U.S. 51 (1979)' (depriving individual of the right to transfer property (eagle feathers) does not constitute a taking under the Fifth Amendment). The inseparability of our conception of private property from its transferability is not necessarily a characteristic of government entitlements and other forms of the "new property." See Reich, The New Property, 73 Yale L.J. 733 (1964).

5 Cf. J. Rawls, A Theory of Justice 136-42 (1971).

6 Among other things, the free transferability of property promotes the productive use of assets by ensuring that the property (or a partial interest in it) ends up in the hands of whoever values it the most. See Demsetz, Toward a Theory of Property Rights, 57 Am. Econ. Rev. 347 (Pap. \& Proc. 1967).

7 See 5 w. Holdsworth, A History of English Law 104-05, 11011. The doctrine still survives in England. See Sale of Goods Act $\S 22$.

8 See, e.g., Mowrey v. Walsh, 8 Cowen. 238 (N.Y. 1828); Gilmore, The Commercial Doctrine of Good Faith Purchase, 63 Yale L.J. 1057 (1954).

9 See Gilmore, The Good Faith Purchase Idea and the Uniform Commercial code: Confessions of a Repentant Draftsman, $15 \mathrm{Ga}$. L. 
Rev. 605, 609 (1981).

10 U.C.C. $\$ 2-403(2)$.

11 A seller of goods implicitly warrants to his transferee and subsequent purchasers that he has good title. U.C.C. $\S 2-312$.

12 Weinberg, Sales Law, Economics, and the Negotiability of Goods, 9 J. Legal Studies 569 (1980).

13 But see A. Schwartz \& R. Scott, Commercial Transactions: Principles and Policies 476 (1982).

14 Cf. Epstein, Notice and Freedom of Contract in the Law of Servitudes, 55 S. Cal. L. Rev. 1353, 1355 (1982) ("Who will be prepared to buy a remainder interest, or to accept property as security for a loan, if faced with the specter of having to authenticate title in a subsequent proceeding....").

15 Id.

16 This description of the role a title recordation system plays is, of course, only a first approximation. Some information outside a recording system is legally relevant, such as the question of whether anyone has acquired an interest in the property through adverse possession. 
17 Cf. Janczyk, An Economic Analysis of the Land Title System for Transferring Real Property, $6 \mathrm{~J}$. Legal Studies 213 (1977).

18 To say that identifying fungible goods is not easy is not, of course, to say that it is impossible. Such technologies as the use of radioactive tracers are available, although not generally cost effective.

19 See Jackson \& Kronman, Secured Financing and Priorities Among Creditors, 88 Yale L.J. 1143 (1979); cf. Schwartz, Security Interests and Bankruptcy Priorities: A Review of Current Theories, 10 J. Legal Studies 1 (1981).

20 See 1 G. Gilmore, Security Interests in Personal Property 5-23 (1965).

21 See Baird \& Jackson, Possesion and Ownership: An Examination of the Scope of Article 9, 35 Stan. L. Rev. (1983).

22 Indeed, the drafters of the Uniform Commercial code appeared to try to capture this distinction (albeit unsuccessfully), when they tried to deny buyer in ordinary course status to someone who bought from a pawnbroker. As it happened, because of a mix-up in multiple drafts, the code as written appears to have the rather meaningless requirement that pawnbrokers themselves cannot be buyers in ordinary course. See 
U.C.C. $\$ 1-201(9)$ (1978); U.C.C. $\$ 1-201(9)$ (1952). The requirement is virtually meaningless, because pawnbrokers rarely buy goods from people who regularly deal in goods of the kind, and hence could not qualify as buyers in ordinary course in any event. The section should be read so as to have "pawnbroker" qualify the type of seller, not the type of buyer.

23 With the exception of property that is commonly subject to true leases (today, no small exception), or property temporarily in the hands of a repairer or other bailee, the person who owns tangible personal property is the person who possesses it and uses it. The common law refused to recognized as effective other transfers of personal property that were not accompanied by possession. See, e.g., Sturtevant v. Ballard, 9 Johnson 337,6 Am. Dec. 281 (N.Y. 1812); cf. U.C.C. $\$ 2-402$.

24 1 G. Gilmore, supra note 20, at 146-95; Skilton, Field Warehousing as a Financing Device, 1961 Wis. L. Rev. 221,403 .

25 See generally Baird, Notice Filing and the Problem of Ostensible Ownership, $12 \mathrm{~J}$. Legal Studies 53 (1983).

26 See Baird \& Jackson, supra note 21 .

27 Cases in which serial numbers are changed to defraud creditors arise all too frequently. The Billy sol Estes affair is perhaps the most notorious example. See Estes $v$. United 
States, 335 F.2d 609, 612 (5th Cir. 1964).

28 While there are some remaining "which certificate" issues, they are generally of lesser magnitude. One cannot rely completely on a certificate of title when one buys a used automobile, for example, because the certificate could have been fraudulently obtained and the interest of the true owner could be properly recorded in another jurisdiction of which one is unaware. But these uncertainties may not defeat the overall advantages of determining ownership, in the first instance, from files (or certificates) and not from possession.

29 The relevant statute governing transfers of interests in patents is 35 U.S.C. $\S 261$ ("Any assignment, grant or conveyance [of a patent] shall be void as against any subsequent purchaser or mortgageee for a valuable consideration, without notice, unless it is recorded in the Patent and Trademark Office within three months from its date or prior to the date of such subsequent purchase or mortgage."). The comparable rule for transfers of copyrights is 17 U.S.C. $\$ 204$; the comparable rule for trademarks is 15 U.S.C. $\$ 1060$. A trademark, however, is not assignable apart from the goodwill of the business connected with or symbolized by the mark. For a discussion of the weaknesses inherent in the current copyright filing systems, see Note, Transfers of Copyrights for Security Under the New Copyright Act, 88 Yale L.J. 125 (1978). 
Iowa L. Rev. 231 (1962).

312 G. Gilmore, supra note 20 , at 896.

32 Philbrick, Limits of Record Search and Therefore of Notice (Part I), 93 U. Pa. L. Rev. 125, 128-29 (1944).

33 See Kronman, Mistake, Disclosure, Information, and the Law of Contracts, 7 J. Legal Studies 1 (1978).

34 For example, imagine that $\underline{A}, \underline{B}$, and $\underline{C}$ acquire interests in Blackacre in that order. A fails to file, while both $\underline{B}$ and $\underline{C}$ file properly. B acquired his interest with actual knowledge of A's unrecorded interest; $\underline{C}$ knew nothing about it. A circular priority arises under either a notice or a race-notice system, and it is impossible (in the strong sense) to determine who, among $\underline{A}, \underline{B}$, and $\underline{C}$, should have priority. $\underline{A}$ prevails as against $\underline{B}$, because $\underline{B}$ 's interest arose later in time and $\underline{B}$ had actual knowledge. B prevails as against $\underline{C}$, because $\underline{C}^{\prime}$ s interest arose later in time and $\underline{C}$ was on constructive notice of $\underline{B}^{\prime} s$ interest, because of the proper filing. $\underline{C}$ prevails as against $\underline{A}$, because, although his interest arose later in time, he had neither notice nor actual knowledge of $\underline{A}$ 's interest. $\underline{A}$ beats $\underline{B}$, $\underline{B}$ beats $\underline{C}$, and $\underline{C}$ beats $\underline{A}$. See 2 G. Gilmore, supra note 20 , at 1020-46. Compare Kronman, Specific Performance, 45 U. Chi. L. Rev. 
351 (1978), with Schwartz, The Case for Specific Performance, 89 Yale L.J. 271 (1979).

36 See R. Posner, Economic Analysis of Law 32 n.2, 54 (2d ed. 1977); Landes \& Posner, Private Enforcement of Law, 4 J. Legal Studies 1 (1975); Becker \& Stigler, Law Enforcement, Malfeasance, and Compensation of Enforcers, 3 J. Legal Studies 1 (1974).

37 The bounty would almost certainly have to be paid to the first one to resort to the files to correct the information; almost any other scheme would entail arguments over the prior creditor's state of knowledge, and whether the correction would have been made irrespective of the bounty. (Ironically, the bounty rule itself would thereby eschew knowledge in establishing its entitlements.) But a "first to correct" rule would run a serious risk of resulting in a net decrease in the information conveyed by the files, as the files become cluttered with irrelevant gossip and side information, entered by people hoping to strike the bounty from time to time. The ironic result of this might be a less reliable filing system -- in the sense of it costing more to gain the information needed out of it.

38 See T. Plucknett, A Concise History of the Common Law 611 (5th ed. 1956) ("The essence of the transaction was a complete and public change of the occupancy of the land in question; even the symbolic transfers of the previous age are no longer effective (if, indeed, they ever were); instead, we find the 
purchaser entering upon the land and expelling from it the previous owner and his family, his servants, beasts and chattels, all of which is done in the most public way.").

39 See Morgan's Executors v. Biddle, 1 Yeates 3, 4 (Pa. 1791) ("It is settled in the books, that a bill of sale may be made of a ship either at sea or in port, and the same will be valid in law, provided the vendee reduces her into possession as soon as he conveniently can.").

40 See Noțe, supra note 29, at 129-35. 